\title{
Isolation of squarrosal and squarrosol compounds from methanol root extract of Ruellia squarrosa (Acanthaceae)
}

\author{
Khurram Afzal ${ }^{1,2 *}$, Muhammad Uzair ${ }^{1}$, Bashir Ahmad Chaudhary ${ }^{1}$, Saeed \\ Akhtar $^{2}$, Ashfaq Ahmad ${ }^{3^{\star}}$, Samina Afzal ${ }^{1}$ \\ ${ }^{1}$ Faculty of Pharmacy, ${ }^{2}$ Institute of Food Science and Nutrition, Baha u din Zakariya University, Multan, Pakistan, ${ }^{3}$ Department \\ of Pharmacology and Toxicology, School of Medicine, Virginia Commonwealth University, Richmond 23298, USA
}

*For correspondence: Email: khurram.afzal@bzu.edu.pk

\begin{abstract}
Purpose: To identify, characterize and structurally elucidate bioactive compounds from root of Ruellia squarrosa.

Methods: One kilogram of crude Ruellia squarrosa root was shade dried for 14 days, ground to a fine powder and subjected to a methanol extraction. The resultant extract underwent column chromatography for further purification. The isolated compounds were subjected to ultraviolet spectroscopy (UV), infra-red (IR), proton nuclear magnetic resonance $\left({ }^{1} \mathrm{H}-\mathrm{NMR}\right),{ }^{13} \mathrm{C}-\mathrm{NMR}$ and high resolution electron ionization mass spectrometry (HR-EI-MS) for the identification, characterization and structural elucidation of bioactive compounds. The most active compounds were tested for anticancer activities against human prostate cancer cell.

Results: Two active compounds, squarrosol and squarrosal, were obtained with half-maximal inhibitory concentration $\left(I C_{50}\right)$ of 15.6 and $26.6 \mu \mathrm{g} / \mathrm{mL}$, respectively, against human prostate cancer cell lines. Squarrasol showed a significantly $(p<0.05)$ greater inhibition of cell proliferation than the same dose of squarrasal.

Conclusion: These findings suggest that extracts of Ruellia squarrosa containing the bioactive compounds, squarrosol and squarrosal, can potentially be developed for the treatment of human prostate cancer.
\end{abstract}

Keywords: Ruellia squarrosa, Prostate cancer, Squarrosol, Squarrosal, Anit-proliferative

\begin{abstract}
This is an Open Access article that uses a funding model which does not charge readers or their institutions for access and distributed under the terms of the Creative Commons Attribution License (http://creativecommons.org/licenses/by/4.0) and the Budapest Open Access Initiative (http://www.budapestopenaccessinitiative.org/read), which permit unrestricted use, distribution, and reproduction in any medium, provided the original work is properly credited.
\end{abstract}

Tropical Journal of Pharmaceutical Research is indexed by Science Citation Index (SciSearch), Scopus, International Pharmaceutical Abstract, Chemical Abstracts, Embase, Index Copernicus, EBSCO, African Index Medicus, JournalSeek, Journal Citation Reports/Science Edition, Directory of Open Access Journals (DOAJ), African Journal Online, Bioline International, Open-J-Gate and Pharmacy Abstracts

\section{INTRODUCTION}

Medicinal plants have made a great impact on human health and extracts have been used for treatment of various diseases and have been found to have antimicrobial activity and antiviral activity [1-3]. Researchers have turned their attention towards herbal products as potential sources in their search for more effective drugs in the treatment of cancer, cardiac and infectious diseases [4,5]. Since ancient time, plants and plant extracts have been used traditionally as medicinal remedies and it is estimated that $80-85$ $\%$ of the world population relies on herbal plants and extracts for medicinal purposes [6]. 
The genus Ruellia, generally known as Ruellias or Wild Petunias, belongs to the family Acanthaceae. It includes about 250 genera and 2500 species. Most of these are shrubs or twining vines; some are epiphytes, with most species occurring in tropical regions and only a few being distributed in temperate regions. They are found in Indonesia, Malaysia, Africa, Brazil, Central America and Pakistan. They are represented in Pakistan by 5 species, of which 3 are native [7]. Extracts of different species of genus Ruellia have been reported to possess anti-inflammatory, anti-pyretic [8], antiulcer [9], antiproliferative [10] and antidiabetic activities [11]. The plant Ruellia squarrosa has been used traditionally for the treatment of stomach cancer. Dried root extracts of the plant has been used used to induce abortions and for inflammation in the eyes [12].

The present investigation was conducted in order to extend previous observation [13], in order to isolate the active compounds from plant Ruellia squarrosaand and evaluate their anticancer potential against prostate cancer cell lines by measuring their $\mathrm{IC}_{50}$ values and \% inhibition of proliferation in human prostate cancer cell lines.

\section{EXPERIMENTAL}

\section{Plant collection}

The plant Ruellia squarrosa was collected from the University Garden of Bahauddin Zakariya University (B.Z.U), Multan (District in Punjab, Pakistan) in August, 2013 and identified by Prof. Dr. Altaf Ahmad Dasti, Plant Taxonomist, Institute of Pure and Applied Biology, B.Z.U Multan, Pakistan. A reference specimen (fl.c. 1-2) was deposited in the Institute of Pure and Applied Biology B.Z.U Multan.

\section{Extraction}

Roots of Ruellia squarrosa, $500 \mathrm{~g}$, were shade dried for two weeks and then powdered by using homogenizer. The fine powder was subjected to extraction by mixing with one liter volume of methanol at room temperature for 24 hours. The methanol extract was filtered and dried by rotavapor - R200 at $35^{\circ} \mathrm{C}$ until semisolid appearance of extract was observed in collection flask. A total amount of $35 \mathrm{~g}$ of extract of Ruellia squarrosa was collected in collection flask.

\section{Isolation procedure}

The methanolic extract, about $8 \mathrm{~g}$, was fractionated using silica gel 60 column chromatography and step wise elusion with a mixture of chloroform: methanol: water (70:30:4 $\mathrm{v} / \mathrm{v} / \mathrm{v}$ ) in increasing order of polarity. Six fractions were obtained using this approach. Fraction 3 containing, $370 \mathrm{mg}$, was further fractionated using silica gel 60 column chromatography but with stepwise elution using a ethyl acetate: methanol: water (98: 14: $7 \mathrm{v} / \mathrm{v} / \mathrm{v})$ respectively. As a result, 9 sub-fractions were obtained from which two pure compounds were isolated namely compound squarrosal, approximately $6 \mathrm{mg}$, and squarrosol, of approximately $5 \mathrm{mg}$.

\section{General}

For TLC purposes, aluminum sheets pre-coated with silica gel $60 \mathrm{~F}_{254}(20 \times 20 \mathrm{~cm}, 0.2 \mathrm{~mm}$ thick; E-Merck) were used to check the percentage purity of the compounds. The visualization of components took place under ultraviolet light (254 and $366 \mathrm{~nm}$ ) followed by Godine reagent and $10 \%$ sulphuric acid as a spraying reagent. Column chromatography for isolation purposes used silica gel, 70-230 mesh, and 230-400 mesh along with sephadex LH-20. An IR spectrum was recorded using a Bruker vector-200 spectrophotometer $\left(\mathrm{v}\right.$ in $\left.\mathrm{cm}^{-1}\right)$. The ${ }^{1} \mathrm{H}-\mathrm{NMR}$ spectrum was measured using a Bruker Avon$300 \mathrm{MHz}$ instrument with TMS as an internal standard. The chemical shift values were reported in ppm (ס) units and the coupling constants $(\mathcal{C})$ are recorded in $\mathrm{Hz}$. The ${ }^{13} \mathrm{C}-\mathrm{NMR}$ spectrum was also recorded using the Bruker Avon-300 MHz instrument. El-MS spectrum was measured using a Jeol JMS-600H spectrometer and HREI-MS with a MET-95-XP.

\section{Solvents and materials}

Methanol, dichloromethane, chloroform, nhexane, ethyl acetate, ethanol, propanol, $n$ butanol Vanillin, silica gel (70-230 mesh), TLC aluminum sheets $(20 \times 20) \mathrm{cm}$ and Silica gel 60 $\mathrm{F}_{254}$ were imported from Merck (Darmstadt Germany). Sephadex LH-20 25 - $100 \mathrm{um}$ and Fluka Chemie GmbH (9041-37-6).

\section{Chromatographic studies}

The separation and purification of the plant constituents relied mainly on different chromatographic techniques, the choice of which depended upon the property and volatility of compound to being identified or separated.

Biological application of these compounds on prostate cancer cell lines

An MTT assay was performed as reported previously [13]. Briefly, human prostate cancer 
cells (ATCC, USA) were cultured in Dulbecco's Modified Eagle's Medium (DMEM) containing 5 $\%$ foetal bovine serum were kept at $5 \%$ incubator at $37{ }^{\circ} \mathrm{C}$.

Growing cells were cultivated, harvested and diluted with a specific medium. $(5-10) x$ $10^{4}$ cells/well were treated for $48 \mathrm{~h}$ with six different concentrations of squarrosol and squarrosal in $\mu \mathrm{g} / \mathrm{mL}(2.5-25 \mathrm{ug} / \mathrm{ml})$. $0.5 \%$ dimethyl sulfoxide (DMSO) and 5 fluorouracil (5FU) were used as negative and positive control substances, respectively. Absorbance was read using a microplate reader (TECAN Infinite Pro ${ }^{\circledR} \mathrm{M} 200$, Switzerland) at $570 \mathrm{~nm}$ using $620 \mathrm{~nm}$ as the reference wavelength.

\section{Statistical analysis}

The results presented are mean $\pm S D$. One-way ANOVA was performed to test differences between groups which were considered significant at $p<0.05$. GraphPad Prism (Graph PAD, San Diego, USA) was used for statistical analysis.

\section{RESULTS}

\section{Physical and spectroscopic characteristics}

\section{Squarrosal}

UV (Me OD) $\lambda_{\max } \log \varepsilon \mathrm{nm}: 212$ (1.2); IR $\mathrm{IU}_{\max }(\mathrm{KBR})$ $\mathrm{cm}^{-1}:$ 2926, 2856, 1739, 1593, 1452, 1184, 1132, 860; ${ }^{1} \mathrm{H}-\mathrm{NMR}$ (DMSO, 500MHz): $87.93(1 \mathrm{H}, \mathrm{s}$, $\mathrm{H}-1), 7.92(1 \mathrm{H}, \mathrm{d}, J=7.0, \mathrm{H}-2, \mathrm{H}-3), 7.24(1 \mathrm{H}, \mathrm{d}$, $J=6.8, \mathrm{H}-2, \mathrm{H}-4), 1.58(1 \mathrm{H}, \mathrm{t}, J=2.8, \mathrm{H}-2, \mathrm{H}-$ 7), $6.47(1 \mathrm{H}, \mathrm{s}, \mathrm{H}-9), 2.69(2 \mathrm{H}, \mathrm{q}, J=6.4, \mathrm{H}-2, \mathrm{H}-$ 12), $0.74(3 \mathrm{H}, \mathrm{t}, J=2.5, \mathrm{H}-13), 1.16(2 \mathrm{H}, \mathrm{dt}, J=$ 2.9,3.7, H-14), $1.15(2 \mathrm{H}, \mathrm{dt}, \mathrm{J}=2.0, \mathrm{H}-15), 1.69(1 \mathrm{H}$, $\mathrm{m}, \mathrm{H}-16), 6.16(1 \mathrm{H}, \mathrm{dd}, J=6.0,5.0, \mathrm{H}-17), 6.18$ $(1 \mathrm{H}$, dd, $J=6.8,5.1, \mathrm{H}-18), 6.45(1 \mathrm{H}, \mathrm{dd}, J=5.9$, 7.0, $\mathrm{H}-19), 4.42(1 \mathrm{H}, \quad \mathrm{dd}, \quad J=6.1, \quad 6.8, \quad \mathrm{H}-$ 20), $5.55(1 \mathrm{H}, \mathrm{d}, \mathrm{J}=7.8, \mathrm{H}-21) 3.84$

$(1 \mathrm{H}, \mathrm{dd}, J=7.2,5.0, \mathrm{H}-22) 3.61 \quad(1 \mathrm{H}, \mathrm{dd}, \quad J=5.7,3.9$, $\mathrm{H}-23) 3.60(1 \mathrm{H}, \mathrm{dd}, J=7.3,4.7, \mathrm{H}-24), 6.12(1 \mathrm{H}, \mathrm{d}$, $J=6.5, \quad \mathrm{H}-25) ;{ }^{13} \mathrm{C}-\mathrm{NMR}\left(\mathrm{CDCl}_{3}, 125 \mathrm{MHz}\right): \delta$ 128.0 (C-1), 130.0 (C-2), 125.0 (C-3), 124.0 (C4), 131.0 (C-5), 167.0 (C-6), 50.0 (C-7), 115.0 (C-8), 142.0 (C-9), 137.0 (C-10), 141.6 (C-11), 67.9 (C-12), 63.0 (C-13), 23.7 (C-14), 39.7(C15), 29.3 (C-16), 154.6(C-17)131.3 (C-18), 131.0(C-19), 154.0 (C-20), 92.5 (C-21), 77.2 (C22)77.0 (C-23), 76.7(C-24), 97.6(C-25): EI-MS $\mathrm{m} / \mathrm{z}$ (rel. int): 413(400), 219(240), 166(243); HREl-MS $m / z$ : $456[\mathrm{M}+\mathrm{H}]^{+}$(calculated for $\mathrm{C}_{25} \mathrm{H}_{28} \mathrm{O}_{8}$ : 456).<smiles></smiles>

Figure 1: Structure of squarrosal

Squarrosal was isolated from the methanol fraction of Ruellia squarrosa as an amorphous powder. The infrared spectrum of the compound had absorption bands at $1739 \mathrm{~cm}^{-1}$ due to lactone group. A band was observed at $1593 \mathrm{~cm}^{-1}$ due to aromaticity. The stretching vibrations at 2856 $\mathrm{cm}^{-1}$ showed the presence of $\mathrm{sp}^{3} \mathrm{C}-\mathrm{H}$ and at $2925 \mathrm{~cm}^{-1}$ showed the presence of $\mathrm{Sp}^{2} \mathrm{C}-\mathrm{H}$.

The ultraviolet visible spectrum of the compound demonstrated an absorption band at $212 \mathrm{~nm}$. The molecular formula was inferred as $\mathrm{C}_{25} \mathrm{H}_{28} \mathrm{O}_{8}$ through the JEOLJMS-600H presenting a molecular ion peak $[\mathrm{M}+\mathrm{H}]$ at $\mathrm{m} / \mathrm{z} 456$ (calculated for $\mathrm{C}_{25} \mathrm{H}_{28} \mathrm{O}_{8}: 456$ ) (Table 2). The mass fragmentation of the compound is given in Figure 1:

The ${ }^{1} \mathrm{H}$-NMR spectrum of squarrosal showed a signal for an alcoholic group at $\delta 3.61(1 \mathrm{H}, \mathrm{dd}, J=$ $3.9,5.7 \mathrm{~Hz}), 3.84(1 \mathrm{H}, \mathrm{dd}, J=5.0,7.2 \mathrm{~Hz})$ and $3.60(1 \mathrm{H}, \mathrm{dd}, J=4.7,7.3 \mathrm{~Hz})$. The aliphatic ring protons appeared at $\delta 2.94(2 \mathrm{H}, \mathrm{d}, J=2.6 \mathrm{H})$, $1.16(2 \mathrm{H}, \mathrm{dt}, J=2.1,3.7 \mathrm{~Hz})$; the methyl group appeared at $\delta 0.74(3 \mathrm{H}, \mathrm{t})$; and the lactone hydrogen at $\delta 5.55(1 \mathrm{H}, \mathrm{d}, J=7.8, \mathrm{~Hz})$.

The ${ }^{13} \mathrm{C}$-NMR spectrum (BB and DEPT) of squarrosal exhibited 25 carbon signals for one methyl, fifteen methines, four methylenes and five quaternary carbon atoms. The downfield signal at $\delta 167.6,141.6$ showed the presence of carbonyl carbon group. The lactone ring appeared at $\delta 92.5$ and 97.6; the aliphatic carbon appeared at $\delta 1.176$ to 2.94 ; and the alcoholic peak was observed at $\delta 77.2,70.0$ and 76.7.

On the basis of these data, the structure was established as 2-(2-(cyclopenta-2,4-dien-1yl)ethyl)-3-(2-oxopropyl)-6-(3,4,5,6

tetrahydroxytetrahydro-2H-pyran-2-yl)-3,4-

dihydronaphthalen-1(2H)-one and it was found to be a novel natural product. It was named on the basis of the species as squarrosal. 
Table 1: ${ }^{13} \mathrm{C}-\mathrm{NMR}$ and chemical shift assignments of squarrosal

\begin{tabular}{lcccc}
\hline $\begin{array}{l}\text { Carbon } \\
\text { no. }\end{array}$ & DEPT & $\begin{array}{c}{ }^{13} \mathbf{C}- \\
\text { NMR }\end{array}$ & 'H-NMR & $\begin{array}{c}\text { J. } \\
\text { Value }\end{array}$ \\
\hline $\mathrm{C}-1$ & $\mathrm{CH}$ & 128.0 & $7.93(\mathrm{~s})$ & - \\
$\mathrm{C}-2$ & $\mathrm{C}$ & 130.0 & - & - \\
$\mathrm{C}-3$ & $\mathrm{CH}$ & 125.0 & $7.92(\mathrm{~d})$ & 7.0 \\
$\mathrm{C}-4$ & $\mathrm{CH}$ & 124.0 & $7.24(\mathrm{~d})$ & 6.8 \\
$\mathrm{C}-5$ & $\mathrm{C}$ & 131.0 & - & - \\
$\mathrm{C}-6$ & $\mathrm{C}$ & 167.0 & - & - \\
$\mathrm{C}-7$ & $\mathrm{CH}$ & 50.0 & $1.58(\mathrm{t})$ & 2.8 \\
$\mathrm{C}-8$ & $\mathrm{C}$ & 115.0 & - & - \\
$\mathrm{C}-9$ & $\mathrm{CH}$ & 142.0 & $6.47(\mathrm{~s})$ & - \\
$\mathrm{C}-10$ & $\mathrm{C}$ & 137.0 & - & - \\
$\mathrm{C}-11$ & $\mathrm{C}$ & 141.6 & - & - \\
$\mathrm{C}-12$ & $\mathrm{CH}$ & 67.9 & $2.69(\mathrm{q})$ & 6.4 \\
$\mathrm{C}-13$ & $\mathrm{CH}$ & 63.0 & $0.74(\mathrm{t})$ & 2.5 \\
$\mathrm{C}-14$ & $\mathrm{CH}$ & 23.7 & $1.16(\mathrm{dt})$ & 2.9 \\
& & & & 3.7 \\
$\mathrm{C}-15$ & $\mathrm{CH}$ & 39.7 & $1.15(\mathrm{dt})$ & 2.0 \\
& & & & 4.5 \\
$\mathrm{C}-16$ & $\mathrm{CH}$ & 29.3 & $1.69(\mathrm{~m})$ & - \\
$\mathrm{C}-17$ & $\mathrm{CH}$ & 154.6 & $6.16(\mathrm{dd})$ & $6.0,5.0$ \\
$\mathrm{C}-18$ & $\mathrm{CH}$ & 131.3 & $6.18(\mathrm{dd})$ & 6.8, \\
& & & & 5.1 \\
$\mathrm{C}-19$ & $\mathrm{CH}$ & 131.0 & $6.45(\mathrm{dd})$ & $5.9,7.0$ \\
$\mathrm{C}-20$ & $\mathrm{CH}$ & 154.0 & $4.42(\mathrm{dd})$ & $6,1,6.8$ \\
$\mathrm{C}-21$ & $\mathrm{CH}$ & 92.5 & $5.55(\mathrm{~d})$ & 7.8 \\
$\mathrm{C}-22$ & $\mathrm{CH}$ & 77.2 & $3.84(\mathrm{dd})$ & $7.2,5.0$ \\
$\mathrm{C}-23$ & $\mathrm{CH}$ & 77.0 & $3.61(\mathrm{dd})$ & $5.7,3.9$ \\
$\mathrm{C}-24$ & $\mathrm{CH}$ & 76.7 & $3.60(\mathrm{dd})$ & $7.3,4.7$ \\
$\mathrm{C}-25$ & $\mathrm{CH}$ & 97.6 & $6.12(\mathrm{~d})$ & 6.5 \\
\hline & & & &
\end{tabular}<smiles>CCOC1=CC2=CC(c3ccc4c(c3)C(O)C(O)C(O)C4)C(OCC)C1C2CCC1C=CC=C1</smiles>
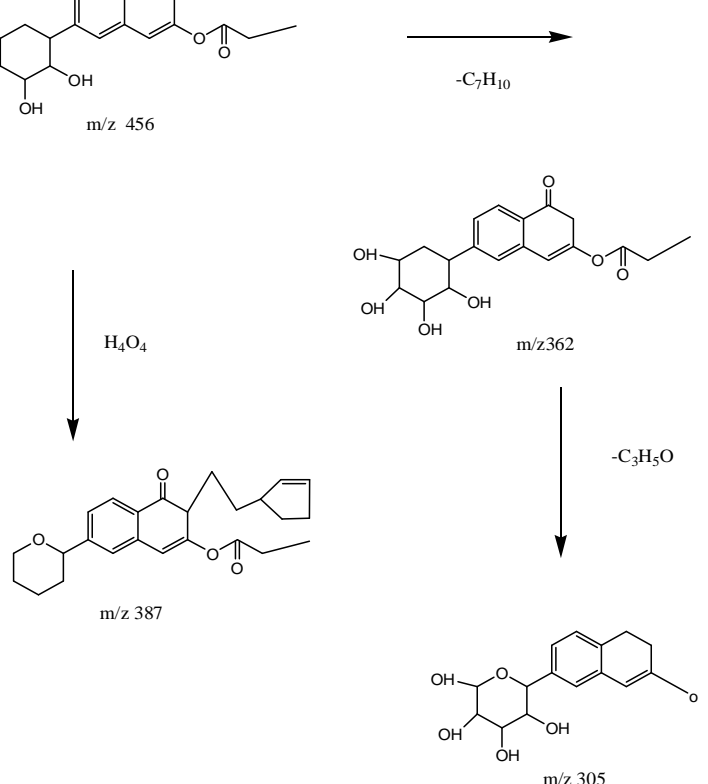

Figure 2: Mass fragmentation of compound squarrosal

\section{Squarrosol}

Non crystalline solid (05 mg); UV (Me OD) $\lambda_{\text {max }}$ logenm: 208 (0.65), 284 (0.14); IR $U_{\max }(K B R)$ $\mathrm{cm}^{-1}: 3463,3060 ;{ }^{1} \mathrm{H}-\mathrm{NMR}$ (DMSO, 500MHz): ס7.65 (1H, s, H-1), $7.67(1 \mathrm{H}, \mathrm{s}, \mathrm{H}-3), 4.40(1 \mathrm{H}, \mathrm{d}$, $J=7.0, \mathrm{H}-8), 4.45(1 \mathrm{H}, \mathrm{d}, J=6.8 \mathrm{H}-9), 7.46(1 \mathrm{H}$, $\mathrm{d}, \mathrm{J}=7.2, \mathrm{H}-12), 7.48(1 \mathrm{H}, \mathrm{d}, J=6.8, \mathrm{H}-13), 7.70$ (1H, s, H-15), $0.86(3 \mathrm{H}, \mathrm{s}, \mathrm{H}-16), 7.65(1 \mathrm{H}, \mathrm{s}, \mathrm{H}-$ 19), $7.67(1 \mathrm{H}, \mathrm{s}, \mathrm{H}-21), 6.9(1 \mathrm{H}, \mathrm{s}, \mathrm{H}-24), 6.43$ (1H, m, J=6.8, H-26), 4.39 (2H, d, J=7.8, H-27), 4.37 (3H, s, H-28); ${ }^{13} \mathrm{C}-\mathrm{NMR}\left(\mathrm{CDCl}_{3}, 125 \mathrm{MHz}\right)$ : ס131.8 (C-1), 131.7 (C-2), 129.2 (C-3), 132.4 (C4), 109.5 (C-5), 140.0 (C-6), 167.5 (C-7), 128.7 (C-8), 128.6 (C-9), 116.8 (C-10), 134.5 (C-11), 116.3 (C-12), 121.8 (C-13), 128.7 (C-14), 115.8 (C-15), 22.2 (C-16), 164.4 (C-17), 102.3 (C-18), 131.7 (C-19), 117.6 (C-20), 118.6 (C-21), 114.2 (C-22), 131.8 (C-23), 72.5 (C-24), 132.8 (C-25), 116.8(C-26), 135.6(C-27), 60.8(C-28); El-MS m/z: 484(10), 443(20), 399 (34), 354(30), 132 (42), 89(62), 65(76) HR-El-MS m/z: $484[\mathrm{M}+\mathrm{H}]^{+}$ (calculated for $\mathrm{C}_{28} \mathrm{H}_{24} \mathrm{~N}_{2} \mathrm{O}_{6}: 484$ )<smiles>C=Cc1cc2c(C(=O)Nc3ccc(O)c(C=CC(=O)c4c(C)cc(O)cc4O)c3)c[nH]c2cc1OC</smiles>

Figure 3: Structure of squarrosol

Squarrosol was isolated as a noncrystalline solid from the methanolic extract of Ruellia squarrosa. In the Infrared spectrum of the Squarrosol compound, the absorption bands at $1726 \mathrm{~cm}^{-1}$ was consistent with the presence of a carbonyl functional group. The stretching vibrations at $34.63 \mathrm{~cm}^{-1}$ suggested the presence of $\mathrm{Sp}^{2} \mathrm{C}-\mathrm{H}$. The ultraviolet visible spectrum displayed absorption peaks at 208 and $284 \mathrm{~nm}$. The molecular formula was inferred as $\mathrm{C}_{28} \mathrm{H}_{24} \mathrm{~N}_{2} \mathrm{O}_{6}$ using the JEOLJMS-600H which displayed a molecular ion peak $[\mathrm{M}+\mathrm{H}]$ at $\mathrm{m} / \mathrm{z} 484$ (calculated for $\mathrm{C}_{28} \mathrm{H}_{24} \mathrm{~N}_{2} \mathrm{O}_{6}: 484$ ) (Table 3).

The ${ }^{1} \mathrm{H}$-NMR spectrum of the Squarrosol compound gave a signal for aromatic ring protons $\delta 7.67(1 \mathrm{H}, \mathrm{s}), 7.41(1 \mathrm{H}, \mathrm{d}, J=6.5 \mathrm{~Hz})$, $7.69(1 \mathrm{H}, \mathrm{d}, J=6.8 \mathrm{~Hz}) 7.46(1 \mathrm{H}, \mathrm{d}, J=7.2 \mathrm{~Hz})$, $7.48(1 \mathrm{H}, \mathrm{d}, J=6.8 \mathrm{~Hz}), 7.65(1 \mathrm{H}, \mathrm{s})$ and 7.67 $(1 \mathrm{H}, \mathrm{s})$. The alkene proton showed doublet and multiplets at $\delta 4.40(1 \mathrm{H}, \mathrm{d}, J=7.0 \mathrm{~Hz}) 4.45(1 \mathrm{H}$, $\mathrm{d}, J=6.8 \mathrm{~Hz})$ and $4.39(1 \mathrm{H}, \mathrm{d}, J=7.8 \mathrm{~Hz})$.

The ${ }^{13} \mathrm{C}-\mathrm{NMR}$ spectrum (BB and DEPT) of the Squarrosol compound was consistent with a total of 28 carbon signals for two methyl, eleven methines, one methylene and 14 quaternary carbon atoms. The downfield signal at $\delta 167.5$, 163.1, 161.7 revealed the presence of a $C=0$ group. The downfield signal appeared at $\delta 140.0$, 
135.6, 131.8 indicating the presence of an aromatic functional group.

The compound structure was established as (E)$\mathrm{N}$-(3-(3-(2, 4-dihydroxy-6-methylphenyl)-3oxoprop-1-enyl)-4-hydroxyphenyl)-6-methoxy-5vinyl-1H-indole-3-carboxamide. On the basis of the above data, the compound was identified as a novel natural product and named on the bases of the species as squarrosol.

Table 2: ${ }^{13} \mathrm{C}-\mathrm{NMR}$ chemical shift assignments of squarrosol

\begin{tabular}{lcccc}
\hline $\begin{array}{l}\text { Carbon } \\
\text { no. }\end{array}$ & DEPT & $\begin{array}{c}{ }^{3} \text { C- } \\
\text { NMR }\end{array}$ & $\begin{array}{c}\text { 'H- } \\
\text { NMR }\end{array}$ & J.value \\
\hline $\mathrm{C}-1$ & $\mathrm{CH}$ & 131.8 & $7.65(\mathrm{~s})$ & - \\
$\mathrm{C}-2$ & $\mathrm{C}$ & 131.7 & - & - \\
$\mathrm{C}-3$ & $\mathrm{CH}$ & 129.2 & $7.67(\mathrm{~s})$ & - \\
$\mathrm{C}-4$ & $\mathrm{C}$ & 132.4 & - & - \\
$\mathrm{C}-5$ & $\mathrm{C}$ & 109.5 & - & - \\
$\mathrm{C}-6$ & $\mathrm{C}$ & 140.0 & - & - \\
$\mathrm{C}-7$ & $\mathrm{C}$ & 167.5 & & - \\
$\mathrm{C}-8$ & $\mathrm{CH}$ & 128.7 & $4.40(\mathrm{~d})$ & 7.0 \\
$\mathrm{C}-9$ & $\mathrm{CH}$ & 128.6 & $4.45(\mathrm{~d})$ & 6.8 \\
$\mathrm{C}-10$ & $\mathrm{C}$ & 116.8 & - & - \\
$\mathrm{C}-11$ & $\mathrm{C}$ & 134.5 & - & - \\
$\mathrm{C}-12$ & $\mathrm{CH}$ & 116.3 & $7.46(\mathrm{~d})$ & 7.2 \\
$\mathrm{C}-13$ & $\mathrm{CH}$ & 121.8 & $7.48(\mathrm{~d})$ & 6.8 \\
$\mathrm{C}-14$ & $\mathrm{C}$ & 128.7 & - & - \\
$\mathrm{C}-15$ & $\mathrm{CH}$ & 115.8 & $7.70(\mathrm{~s})$ & - \\
$\mathrm{C}-16$ & $\mathrm{CH}$ & 22.2 & $0.86(\mathrm{~s})$ & - \\
$\mathrm{C}-17$ & $\mathrm{C}$ & 164.4 & - & - \\
$\mathrm{C}-18$ & $\mathrm{C}$ & 102.3 & - & - \\
$\mathrm{C}-19$ & $\mathrm{CH}$ & 131.7 & $7.65(\mathrm{~s})$ & - \\
$\mathrm{C}-20$ & $\mathrm{C}$ & 117.6 & - & - \\
$\mathrm{C}-21$ & $\mathrm{CH}$ & 118.6 & $7.67(\mathrm{~s})$ & - \\
$\mathrm{C}-22$ & $\mathrm{C}$ & 114.2 & - & - \\
$\mathrm{C}-23$ & $\mathrm{C}$ & 131.8 & - & - \\
$\mathrm{C}-24$ & $\mathrm{CH}$ & 72.5 & $6.91(\mathrm{~s})$ & - \\
$\mathrm{C}-25$ & $\mathrm{C}$ & 132.8 & - & - \\
$\mathrm{C}-26$ & $\mathrm{CH}$ & 116.8 & 6.43 & - \\
$\mathrm{C}-27$ & $\mathrm{CH} 2$ & 135.6 & $4.39(\mathrm{~d})$ & 7.8 \\
$\mathrm{C}-28$ & $\mathrm{CH}$ & 60.8 & $4.37(\mathrm{~s})$ & - \\
\hline & & & & \\
\hline
\end{tabular}

\section{Effect of squarrosal and squarrosol of cell proliferation}

The results were presented as percent viability compared to the negative control (mean $\pm S D$, $n=3)$. IC50 values were calculated using the antiproliferation activity of different concentrations of squarrosol and squarrosal as 15.6 and 26.6 $\mu \mathrm{g} / \mathrm{mL}$ respectively. Dose of dependent inhibition on prostate cell proliferation is shown in Figure 4.

\section{DISCUSSION}

The present study was based on the isolation of phytochemical constituents from the herbal plant Ruellia squarrosa and evaluation of active compounds for their anti-proliferative activity on



Figure 4: Dose-dependent activity of squarrosal and squarrosol on prostate cell proliferation. ${ }^{*} P<0.05$ vs. ose of squarrosal; $\# p<0.05$ vs. dose of $5-\mathrm{FU}$

human prostate cancer cell lines. The present investigation isolated two novel compounds from methanol extract of Ruellia squarrosa which belong to the flavonoid class and were named squarrosal and squarrosol. Their anticancer potential against human prostate cancer cell lines was explored as this feature has been established with other flavonoids [14]. This study reported herein represents a continuation of our previous finding [13] in which it was found that extracts of different parts of the Ruellia squarrosa plant contain compounds which possess anticancer potential against human prostate cancer lines. However, the previous study was unable to isolate the active compounds. The current investigation set out to isolate the active constituents of Ruellia squarrosa. It was found that squarrosol and squarrosal both exhibited dose dependent inhibition of proliferation of the prostate cancer cells. Squarrosol exhibited a significantly greater $(p<0.05) \%$ inhibition of proliferation against prostate cancer cell lines when compared to that of squarrosal. However, this activity was less than the degree of inhibition of prostate cancer cell proliferation using the standard drug, 5-FU. These flavonoids are amongst the few medicinal plants which have been reported to have anticancer potential and this activity is in line with the flavones which have been reported to have broad activity against tumors, leukemia, lymphomas and solid tumors [15]. This study is also in line with recent study [13] which demonstrated that flavonoids may be potential therapeutic compounds for the treatment of cancer.

\section{CONCLUSION}

These findings show that squarrosal and squarrosol are the main active compounds contained in the extracts of Ruellia squarrosa and exert antiproliferative effect on human 
prostate cancer cells. Thus, these compounds can potentially be developed for human prostate cancer therapy.

\section{DECLARATIONS}

\section{Acknowledgement}

The work was supported by BZ University Multan, Pakistan. We also acknowledge the technical support of HEJ Research Institute of Chemistry, International Center for Chemical \& Biological Sciences (ICCBS), University of Karachi-75270, Karachi, Pakistan.

\section{Conflict of interest}

No conflict of interest is associated with this study.

\section{Contribution of authors}

We declare that this work was done by the authors named in this article and all liabilities pertaining to claims relating to the content of this article will be borne by the authors. Khurram Afzal and Muhammad Uzair contributed equally to the work.

\section{REFERENCES}

1. Chin YW, Balunas MJ, Chai HB, Kinghorn $A D$. Drug discovery from natural sources. The AAPS J 2006; 8(2): E239-E253.

2. Barbour EK, Al Sharif M, Sagherian VK, Habre AN, Talhouk RS, Talhouk SN. Screening of selected indigenous plants of Lebanon for antimicrobial activity. $J$ Ethnopharmacol 2004; 93(1): 1-7.

3. Weldegerima B. Review on the importance of documenting ethno pharmacological information on medicinal plants. Afr J Pharm Pharmacol 2009; 3(9): 400-403.

4. Yasunaka K, Abe F, Nagayama A, Okabe H, LozadaPérez L, López-Villafranco $E$, Reyes-Chilpa $R$. Antibacterial activity of crude extracts from Mexican medicinal plants and purified coumarins and xanthones. $J$ ethnopharmacol 2005; 97(2): 293-299.

5. Posey DA. Kayapó Ethnoecology and culture. Studies environmental anthropology. Edited by Roy Ellen. London, University of Kent at Canterbury.2002

6. Ignacimuthu $S$, Ayyanar $M$, Sivaraman SK. Ethnobotanical investigations among tribes in Madurai district of Tamil Nadu (India).J Ethnobiol Ethnomed 2006; 2 (25): 1-7.

7. Nasir E, Ali SI. "Flora of West Pakistan No. 1-190. Pakistan Agriculture Research Council, Islamabad". 1971-1991

8. Alam MA, Subhan N, Awal MA, Alam MS, Sarder M, Nahar L, Sarker SD. Antinociceptive and antiinflammatory properties of Ruellia tuberosa. Pharm Biol 2009; 47(3): 209-214.

9. Kumar PPS, Pardhasaradhi P. Preliminary phytochemical investigation and anti-ulcer activity of aerial parts of Ruellia tuberosa L. (Acanthaceae) in male Wistar rats. Int J Pharm 2013; 4(3): 145-148.

10. Dey S, Roy S, Deb N, Sen KK, Besra SE. Anticarcinogenic activity of Ruellia tuberosa. (Acanthaceae) leaf extract on hepatoma cell line and increased superoxide dismutase activity on macrophage cell lysate. IntJ Pharm Pharma Sci 2013; 5(3): 854-861.

11. Rajan M, Kumar VK, Kumar PS, Swathi KR, Haritha S. Antidiabetic, anti-hyperlipidaemic and hepatoprotective activity of methanolic extract of Ruellia tuberosa Linn leaves in normal and alloxan induced diabetic rats. $J$ Chem Pharm Res 2012; 4(6): 2860-2868.

12. Reddy MB, Reddy KR, Reddy MN. Ethnobotany of Cuddapah district, Andhra Pradesh, India. Int $J$ Pharmacog 1991; 29(4): 273-280

13. Afzal MK, Uzair M, Chaudhry BA. Anticancer activity of Ruellia squarrosa against human prostate cancer cell line. Bang J Pharmacol2015; 10(1): 97-99.

14. Kanadaswami C, Lee LT, Lee PPH, Hwang JJ, Ke FC, Huang YT,LEE MT. The antitumor activities of flavonoids. In vivo2005; 19(5): 895-909.

15. Christian MC, Pluda JM, Ho TC, Arbuck SG, Murgo AJ, Sausville EA. Promising new agents under development by division of cancer treatment, diagnosis, and centers of the National Cancer Institute. Semin Oncol 1997;24(2):219-240 